\title{
Virtual reality as training technology in the health field: a literature review
}

\section{A realidade virtual como tecnologia de formação na área da saúde: uma revisão de literatura}

\author{
Isabela Cristina de Miranda Gonçalves ${ }^{1 *}$, Brenda Chayná do Nascimento Pereira ${ }^{1}$, Cassiane \\ Nogueira Santos ${ }^{1}$, Shirley Maria de Araújo Passos ${ }^{1}$, Waldeyde Oderilda Magalhães dos Santos ${ }^{1}$, \\ Giovanna Gonçalves Duarte ${ }^{1}$, João da Mata Libório Filho
}

\begin{abstract}
The present work is an integrative review that aims to answer the following guiding question: how is virtual reality being applied as an educational technology in the health area? The databases used for the search were Pubmed, Virtual Health Library (VHL) in the health area, IEEEXplore and ACM Digital Library in the technology area. For this work, the following inclusion criteria were established: studies on the use of simulators as educational technology; free access articles; be available online in full; be in Portuguese and / or English; published from 2015 to 2020. Articles of literature review, dissertations, theses and editorials were excluded. A total of 1,563 articles were obtained, of which 21 went on to descriptive analysis. Most of the articles came from the Pubmed database, fourteen, six articles were added from the VHL and only one study was included from the ACM. The discussion of the results emerged from two categories: Characterization of the use of virtual reality in the area of health and Considerations on the applicability of virtual reality in the area of health. As a contribution, this review may serve as a guide for the expansion of virtual reality, while pointing out the potential and weaknesses of its use as training technology in the health area
\end{abstract}

Keywords: Health; Virtual reality; Simulation training; Educational technology

\section{RESUMO}

O presente trabalho trata-se de uma revisão integrativa que visa responder a seguinte questão norteadora: de que forma a realidade virtual está sendo aplicada como tecnologia educacional na área da saúde? As bases de dados utilizadas para a busca foram Pubmed, Biblioteca Virtual em Saúde (BVS) na área da saúde, IEEEXplore e ACM Digital Library na área de tecnologia. Para este trabalho foram estabelecidos como critérios de inclusão: estudos sobre uso de simuladores como tecnologia educacional; artigos de livre acesso; disponibilidade online na íntegra; estar no idioma português e/ou inglês; publicado no período de 2015 a 2020. Tendo sido excluídos os artigos de revisão de literatura, dissertações, teses e editoriais foram obtidos 1.563 artigos, dos quais 21 seguiram para a análise descritiva. A maioria dos artigos, quatorze, foram provenientes da base de dados Pubmed, seis artigos foram adicionados da BVS e apenas um estudo foi incluído da ACM. A discussão dos resultados emergiu de duas categorias: Caracterização do uso da realidade virtual na área da saúde e Considerações sobre a aplicabilidade da realidade virtual na área da

\footnotetext{
${ }^{1}$ Universidade do Estado do Amazonas. Escola Superior de Ciências da saúde

*E-mail: igoncalves@uea.edu.br

${ }^{2}$ Universidade do Estado do Amazonas. Centro de Estudos Superiores de Itacoatiara
} 
saúde. Como contribuição, esta revisão poderá servir de norte para a ampliação da realidade virtual ao passo que apontou as potencialidades e fragilidades do seu uso como tecnologia de formação na área da saúde.

Palavras-chave: Saúde; Realidade virtual; Treinamento por simulação; Tecnologia educacional

\section{INTRODUCTION}

Virtual Reality (VR) is conceptualized as a simulation in which an individual making use of an electronic device can interact in a real and/or physical way, with a set of images and sounds that reflect an environment or a real situation. Users can experience visual and auditory sensations through the equipment so that they feel fully participants in the environment being simulated (PARK et al., 2019).

Virtual Reality (VR) applied to health has emerged as a teaching strategy since the 1990s and has appropriated 3D vision to improve the teaching-learning process from human anatomy to a more elaborated simulation (SAMADBEIK et al., 2018). This applicability of VR resulted from the need to train competent professionals, with adequate knowledge and skills to work in clinical practice (MORO et al., 2017).

The applications of virtual reality in health are vast, such as: in the teaching of medical students (EROLIN; REID; MCDOUGALL, 2019); in the planning and surgical training of physicians (SUTHERLAND et al., 2019); and a wide range of therapeutic interventions that cover the treatment of phobias, anxiety disorders, post-traumatic stress disorder (PTSD), accident-related deficits and rehabilitation (BANIASADI; AYYOUBZADEH; MOHAMMADZADEH, 2020).

Although this technology is improving and becoming more portable and realistic, there is much to known about the development, implementation and applications of this technological resource in all its application areas, be it in teaching, training or other therapeutic interventions (COUPERUS et al., 2020).

Knowing how virtual reality it is being used by students and health professionals will help to increase the scientific basis for a possible expansion of the use of this technology, to contribute to more effective actions in the areas of health in which it is used. Thus, the aim of this study was to conduct an integrative review on how educational technologies that make use of virtual reality are being used in the health area. 


\section{METHODS}

To perform this integrative review, the Prisma - Preferred Reporting Items for Systematic Reviews and Meta-Analyses - methodology was used. The study aims to answer the following question guide: how is virtual reality being applied as educational technology in the health area? The databases used for the search were Pubmed, Virtual Health Library (VHL) in the health area, IEEEXplore and ACM Digital Library in technology. The following descriptors were used according to DeCS terminology: Health" AND "Virtual Reality" AND "Patient Simulation"; "Health" AND "Virtual Reality" AND "Simulation Training"; "Health" AND "Virtual Reality" AND "Educational Technology".

A search strategy was developed in 5 stages: 1) selection of studies through the descriptors; 2) reading of titles and abstracts; 3) verification of duplicity; 4) full reading of the articles; 5) analysis of the studies that fulfilled the inclusion criteria, as described in Figure 1.

The inclusion criteria for this study were: studies on the use of simulators as educational technology; open access articles; full online availability; be in Portuguese and/or English languages; published between 2015 and 2020. Literature review articles, dissertations, theses, and editorials were excluded. The selection of articles was carried out in December 2020.

Considering the inclusion and exclusion criteria of the study, 1,563 articles were obtained, of which 21 followed for the descriptive analysis, as it is possible to follow in the flowchart of the study (Figure 1).

To make the word cloud, the software RStudio® (version 1.4.1103) was used, with installation of the packages Bibliometrix and Biblioshiny. In the applied parameters, the Title field was analyzed by measuring the occurrence of the 50 most registered words.

Regarding the analysis of the worldwide production, Microsoft $\AA$ Excel $\AA$ (version 2101) was used, with graphic production of a choropleth map, where publications were recorded by country. 
Figure 1 - Flow of article selection

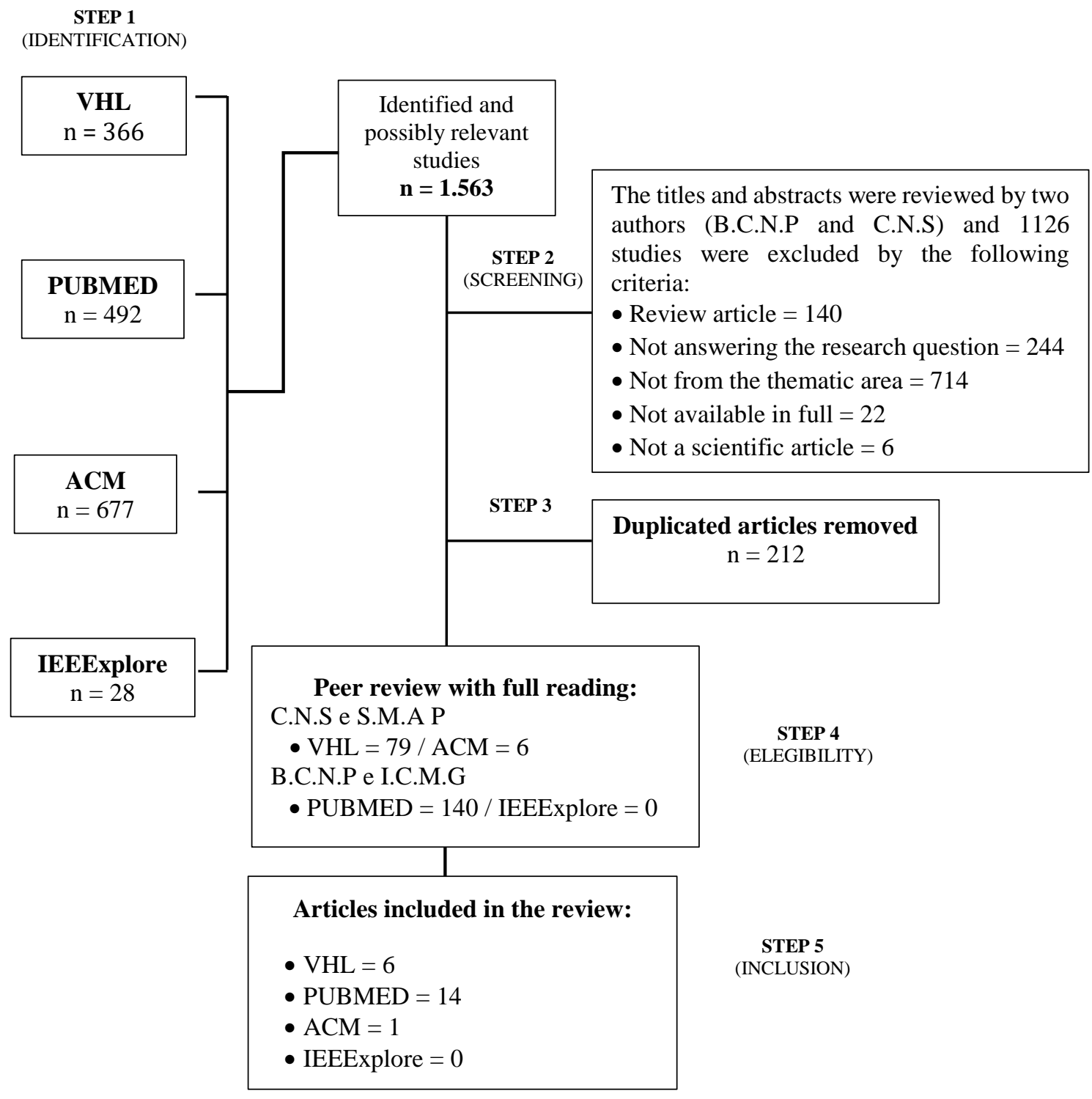

Source: Elaborated by the authors, (2021).

\section{RESULTS}

Considering the objective of this study to conduct a literature review on how virtual reality is being applied as an educational technology in the health area, we observed that its use was restricted to professionals in nursing, medicine, dentistry, pharmacy and occupational therapy. Although the use of virtual reality in the academic scenario was observed, its use was mostly reported for training of health professionals to improve the teaching-learning process and training the skills of a particular technique. 
As for the place of publication, seven articles registered in the United States of America were published, two in Australia and the United Kingdom, while countries such as New Zealand, Sweden, Portugal, China, Canada, Saudi Arabia, Denmark, Switzerland, Malaysia and Brazil registered one article each (Figure 2). Regarding the year of publication of the studies, two (9.5\%) were published in 2015 and 2016, two (9.5\%) in 2017, eight (38.1\%) in the year 2018, seven (33.3\%) in 2019, and two $(9.5 \%)$ in the year 2020.

Figure 2 - Distribution of scientific production by countries in the period from 2015 to 2020

\section{Scientific Production by Country}

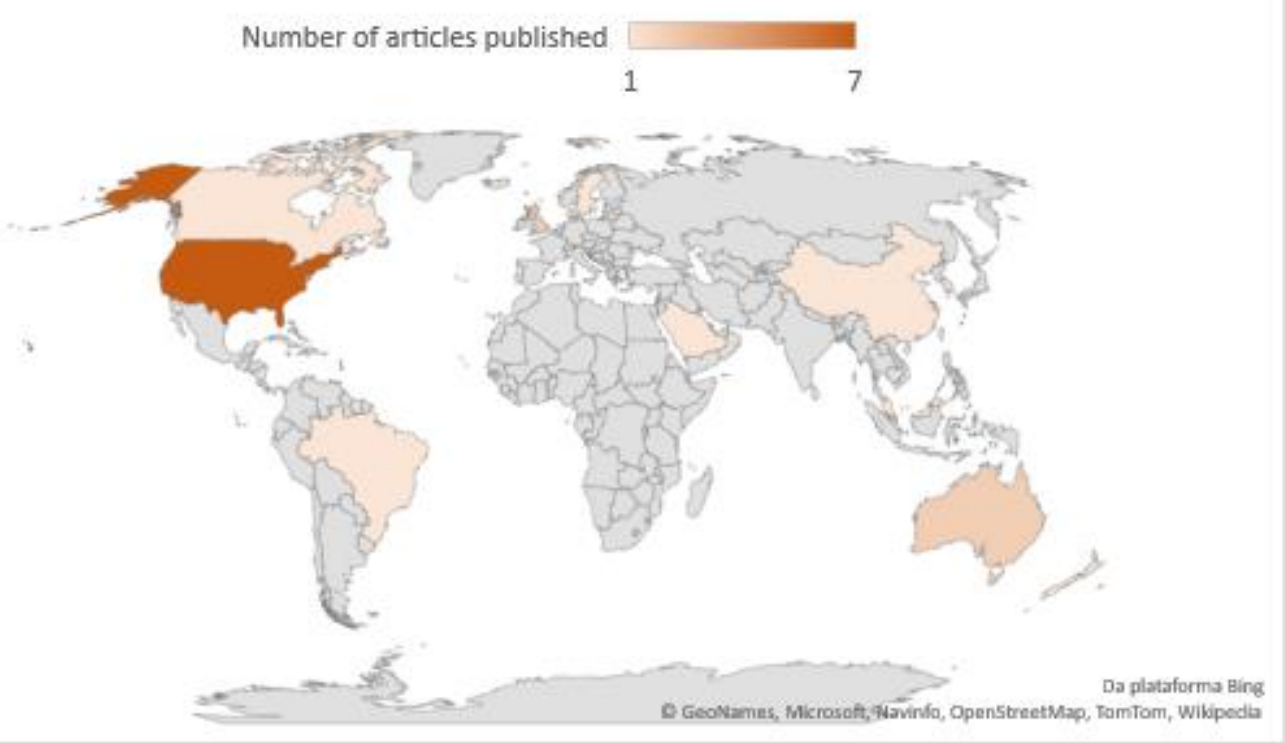

Source: Elaborated by the authors, (2021).

To identify the frequency of keywords listed in the studies contained in the sample, a cloud of words was generated to explain which were the most recurrent concepts. Figure 3 presents the word cloud elaborated from the RStudio software. In this word cloud, the greater the highlight, the greater the number of times the word was used by the authors. By the search criteria, established in the study, it is justifiable that the terms "Reality", "Virtual" and "Simulation" appear prominently. 
Figure 3 - Word cloud

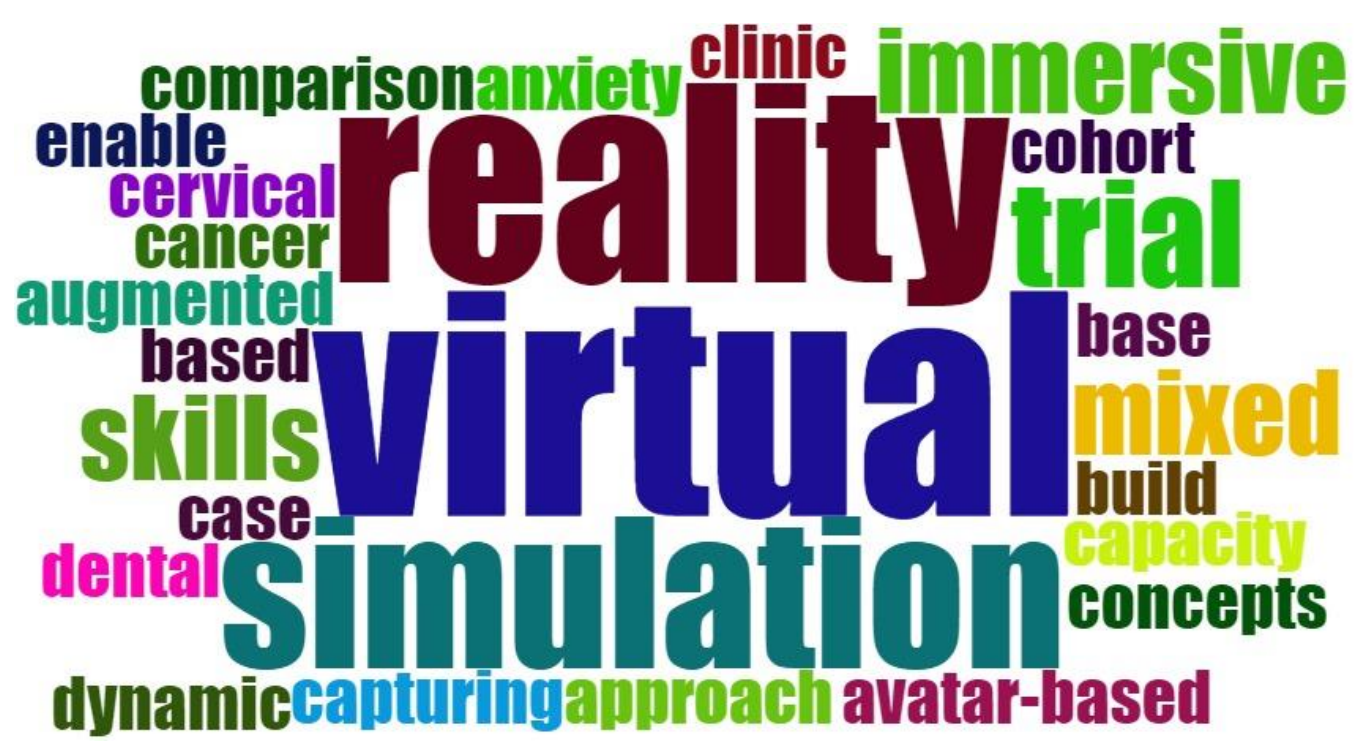

Source: Elaborated by the authors, (2021).

Table 1 presents some specifications of the selected articles synthesized, such as: title, type of tool/ software, theme addressed, study design. Most of the articles (BING et al., 2019; CONCANNON; ESMAIL; ROBERTS, 2020; COURTEILLE et al., 2018; GUETTERMAN et al., 2019; KONGE et al., 2015; LEONG; HERST; KANE, 2018; MIRGHANI et al., 2018; PADILHA et al., 2019; SAPKAROSKI et al., 2018, 2019; SHAO et al., 2020; TAUBERT et al., 2019; YAO; CHALLEN; CAVES, 2019; ZAVERI et al., 2016) came from the PUBMED database (66.7\%). In total, six articles (50.0\%) were found in the VHL (DYER; SWARTZLANDER; GUGLIUCCI, 2018; LAM et al., 2019; MAICHER et al., 2017; SILVA et al., 2017; TSCHOLL et al., 2018; WONG et al., 2018). Only one study (21.4\%) was found in the ACM database (CECIL et al., 2018). When analyzing the study design, five pilot studies were found (BING et al., 2019; DYER; SWARTZLANDER; GUGLIUCCI, 2018; MAICHER et al., 2017; SILVA et al., 2017; TAUBERT et al., 2019), three with mixed research method (GUETTERMAN et al., 2019; LEONG; HERST; KANE, 2018; TSCHOLL et al., 2018), eight randomized clinical trials (COURTEILLE et al., 2018; KONGE et al., 2015; PADILHA et al., 2019; SAPKAROSKI et al., 2018, 2019; SHAO et al., 2020; YAO; CHALLEN; CAVES, 2019; ZAVERI et al., 2016), two prospective cohort studies (CONCANNON; ESMAIL; ROBERTS, 2020; LAM et al., 2019), two experimental studies (CECIL et al., 2018; WONG et al., 2018) and one validation study (MIRGHANI et al., 2018). 
Table 1- Studies included in the integrative review on the use of virtual reality in Health Educational Technologies, published between 2015 and 2020

\begin{tabular}{|c|c|c|c|}
\hline Article Title & $\begin{array}{c}\text { Type of } \\
\text { tool/software }\end{array}$ & $\begin{array}{c}\text { Theme } \\
\text { addressed }\end{array}$ & Study design \\
\hline $\begin{array}{l}\text { Virtual reality videos used in } \\
\text { undergraduate palliative and oncology } \\
\text { medical teaching: results of a pilot } \\
\text { study(TAUBERT et al., 2019) }\end{array}$ & Oculus Rift $360^{\circ}$ & $\begin{array}{l}\text { Palliative and } \\
\text { Oncological } \\
\text { Medicine }\end{array}$ & Pilot study \\
\hline $\begin{array}{l}\text { VERT, a virtual clinical environment, } \\
\text { enhances understanding of radiation } \\
\text { therapy planning concepts(LEONG; } \\
\text { HERST; KANE, 2018) }\end{array}$ & $\begin{array}{l}\text { Virtual Environment } \\
\text { for Radiation } \\
\text { Therapy Training } \\
\text { (VERT) }\end{array}$ & Radiotherapy & $\begin{array}{l}\text { Mixed } \\
\text { methods }\end{array}$ \\
\hline $\begin{array}{l}\text { Medical Students' Experiences and } \\
\text { Outcomes Using a Virtual Human } \\
\text { Simulation to Improve Communication } \\
\text { Skills: Mixed Methods } \\
\text { Study(GUETTERMAN et al., 2019) }\end{array}$ & MPathic-VR & $\begin{array}{l}\text { Empathic and } \\
\text { interprofessional } \\
\text { communication }\end{array}$ & Mixed method \\
\hline $\begin{array}{l}\text { Learning through a virtual patient vs. } \\
\text { recorded lecture: a comparison of } \\
\text { knowledge retention in a trauma } \\
\text { case(COURTEILLE } \text { et al., 2018) }\end{array}$ & Virtual Patient (VP) & $\begin{array}{l}\text { Trauma } \\
\text { education }\end{array}$ & $\begin{array}{l}\text { Randomized } \\
\text { clinical trial }\end{array}$ \\
\hline $\begin{array}{l}\text { Clinical Virtual Simulation in Nursing } \\
\text { Education: Randomized Controlled } \\
\text { Trial(PADILHA et al., 2019) }\end{array}$ & Body Interact & Clinical Nursing & $\begin{array}{l}\text { Randomized } \\
\text { Clinical Trial }\end{array}$ \\
\hline $\begin{array}{c}\text { Virtual reality technology for teaching } \\
\text { neurosurgery of skull base tumor(SHAO } \\
\text { et al., 2020) }\end{array}$ & $\begin{array}{c}\text { Microsoft Hololens }{ }^{\circledR} \\
\text { Unity-3D }\end{array}$ & Neurosurgery & $\begin{array}{l}\text { Randomized } \\
\text { Clinical Trial }\end{array}$ \\
\hline $\begin{array}{l}\text { The implementation of a haptic feedback } \\
\text { virtual reality simulation clinic with } \\
\text { dynamic patient interaction and } \\
\text { communication for medical imaging } \\
\text { students(SAPKAROSKI et al., 2018) }\end{array}$ & CETSOL VR Clinic & $\begin{array}{l}\text { Interaction and } \\
\text { Dynamic } \\
\text { Communication }\end{array}$ & $\begin{array}{l}\text { Randomized } \\
\text { Clinical Trial }\end{array}$ \\
\hline $\begin{array}{l}\text { Quantification of Student Radiographic } \\
\text { Patient Positioning Using an Immersive } \\
\text { Virtual Reality } \\
\text { Simulation(SAPKAROSKI } \text { et al., 2019) }\end{array}$ & CETSOL VR Clinic & $\begin{array}{l}\text { Medical } \\
\text { Radiology }\end{array}$ & $\begin{array}{l}\text { Randomized } \\
\text { Clinical Trial }\end{array}$ \\
\hline $\begin{array}{c}\text { Immersive Virtual Reality for the } \\
\text { Reduction of State Anxiety in Clinical } \\
\text { Interview Exams: Prospective Cohort } \\
\text { Study(CONCANNON; ESMAIL; } \\
\text { ROBERTS, 2020) }\end{array}$ & $\begin{array}{c}\text { VR (HTC Vive) } \\
\text { Unity Technologies }\end{array}$ & $\begin{array}{l}\text { Occupational } \\
\text { Therapy }\end{array}$ & $\begin{array}{l}\text { Prospective } \\
\text { Cohort Study }\end{array}$ \\
\hline $\begin{array}{l}\text { Using Low-Cost Virtual Reality } \\
\text { Simulation to Build Surgical Capacity }\end{array}$ & Oculus Rift & $\begin{array}{l}\text { Surgical } \\
\text { Oncology }\end{array}$ & Pilot Study \\
\hline
\end{tabular}




\begin{tabular}{|c|c|c|c|}
\hline $\begin{array}{c}\text { for Cervical Cancer Treatment(BING et } \\
\qquad a l ., 2019)\end{array}$ & & & \\
\hline $\begin{array}{l}\text { Virtual Reality for Pediatric Sedation: A } \\
\text { Randomized Controlled Trial Using } \\
\text { Simulation(ZAVERI et al., 2016) }\end{array}$ & $\begin{array}{l}\text { Second Life }{ }^{\circledR} \\
\text { SimBaby }\end{array}$ & $\begin{array}{l}\text { Pediatric } \\
\text { Sedation }\end{array}$ & $\begin{array}{l}\text { Randomized } \\
\text { Clinical Trial }\end{array}$ \\
\hline $\begin{array}{c}\text { Capturing differences in dental training } \\
\text { using a virtual reality } \\
\text { simulator(MIRGHANI et al., 2018) }\end{array}$ & Simodont & $\begin{array}{l}\text { Motor Skills in } \\
\text { Dentistry }\end{array}$ & $\begin{array}{l}\text { Content } \\
\text { Validation }\end{array}$ \\
\hline $\begin{array}{c}\text { An Experimental Study on Usefulness of } \\
\text { Virtual Reality } 360^{\circ} \text { In Undergraduate } \\
\text { Medical Education(YAO; CHALLEN; } \\
\text { CAVES, 2019) }\end{array}$ & $360^{\circ} \mathrm{VR}$ & $\begin{array}{l}\text { Medical } \\
\text { Education }\end{array}$ & $\begin{array}{l}\text { Randomized } \\
\text { Clinical Trial }\end{array}$ \\
\hline $\begin{array}{l}\text { Simulator training for endobronchial } \\
\text { ultrasound: a randomised controlled } \\
\text { trial(KONGE } \text { et al., 2015) }\end{array}$ & $\begin{array}{l}\text { GI Bronch Mentor } \\
\text { EBUS Simulator }\end{array}$ & $\begin{array}{l}\text { Endobronchial } \\
\text { USG }\end{array}$ & $\begin{array}{l}\text { Randomized } \\
\text { Clinical Trial }\end{array}$ \\
\hline $\begin{array}{c}\text { Developing a Conversational Virtual } \\
\text { Standardized Patient to Enable Students } \\
\text { to Practice History-Taking } \\
\text { Skills(MAICHER } \text { et al., 2017) }\end{array}$ & $\begin{array}{c}\text { Unity 3D game } \\
\text { ChatScript }\end{array}$ & $\begin{array}{l}\text { Anamnesis in } \\
\text { Medical } \\
\text { Education }\end{array}$ & Pilot Study \\
\hline $\begin{array}{c}\text { Use of virtual games for interactive } \\
\text { learning in a pharmacy curriculum(LAM } \\
\text { et al., 2019) }\end{array}$ & Mimycx & $\begin{array}{l}\text { Interative } \\
\text { Learning in } \\
\text { Pharmacy }\end{array}$ & $\begin{array}{l}\text { Prospective } \\
\text { Cohort Study }\end{array}$ \\
\hline $\begin{array}{l}\text { User perceptions of avatar-based patient } \\
\text { monitoring: a mixed qualitative and } \\
\text { quantitative study(TSCHOLL } \text { et al., } \\
2018)\end{array}$ & Visual Patient & Anesthesiology & Mixed Method \\
\hline $\begin{array}{l}\text { Using virtual reality in medical } \\
\text { education to teach empathy(DYER; } \\
\text { SWARTZLANDER; GUGLIUCCI, } \\
\text { 2018) }\end{array}$ & Oculus Rift & $\begin{array}{l}\text { Empathy } \\
\text { Teaching in } \\
\text { Medical } \\
\text { Education }\end{array}$ & Pilot Study \\
\hline $\begin{array}{l}\text { Clinical instructors' perceptions of } \\
\text { virtual reality in health professionals' } \\
\text { cardiopulmonary resuscitation } \\
\text { education(WONG et al., 2018) }\end{array}$ & $\begin{array}{l}\text { Steam VR } \\
\text { HTC VIVE }\end{array}$ & $\begin{array}{l}\text { Cardiopulmonar } \\
\text { y Resuscitation }\end{array}$ & $\begin{array}{l}\text { Experimental } \\
\text { Study }\end{array}$ \\
\hline $\begin{array}{l}\text { Reducing the Schizophrenia Stigma: A } \\
\text { New Approach Based on Augmented } \\
\text { Reality(SILVA et al., 2017) }\end{array}$ & & Schizophrenia & Pilot Study \\
\hline $\begin{array}{c}\text { A Network-Based Virtual Reality } \\
\text { Simulation Training Approach for } \\
\text { Orthopedic Surgery(CECIL et al., 2018) }\end{array}$ & $\begin{array}{c}\text { HTC Vive } \\
\text { technology } \\
\text { Samsung Gear VR }\end{array}$ & $\begin{array}{l}\text { Orthopedic } \\
\text { Surgery }\end{array}$ & Experimental \\
\hline
\end{tabular}

Source: Elaborated by the authors, (2021). 
It was evident the affirmation of the benefits in the use of virtual reality as a potentiating technology both in the teaching-learning process and in the training of technical skills for the development of a certain procedure between studies.

\section{RESULTS}

Based on the analyzed data, it was possible to point out important questions about the use of virtual reality applied as formative technology in the health area. The discussion of the results emerged from two categories: Characterization of the use of virtual reality in the health area and Considerations about the applicability of virtual reality in the health area.

Characterization of the use of virtual reality in health area

Virtual reality has been used in the health field for didactic development that implies in the teaching-learning process (COURTEILLE et al., 2018; DYER; SWARTZLANDER; GUGLIUCCI, 2018; GUETTERMAN et al., 2019; LAM et al., 2019; LEONG; HERST; KANE, 2018; PADILHA et al., 2019; SHAO et al., 2020; SILVA et al., 2017; TAUBERT et al., 2019; TSCHOLL et al., 2018; WONG et al., 2018) and for training technical skills (BING et al., 2019; CECIL et al., 2018; CONCANNON; ESMAIL; ROBERTS, 2020; KONGE et al., 2015; MAICHER et al., 2017; MIRGHANI et al., 2018; MORO et al., 2017; SAPKAROSKI et al., 2018, 2019; YAO; CHALLEN; CAVES, 2019; ZAVERI et al., 2016) for both academics and health professionals, to train competent professionals, with appropriate knowledge and skills to act professionally.

In the field education, virtual reality has shown to be an ally in the cognitive and psychomotor development of students and professionals. Some studies reveal that health students who used virtual reality tools reported a better ability to concentrate, with a format appropriate to their learning style and very favorable to learning (COURTEILLE et al., 2018; LEONG; HERST; KANE, 2018; TAUBERT et al., 2019). In addition, students who use VR tools in their learning increase conceptual understanding, their level of confidence and level of involvement, stimulation and general opinion (COURTEILLE et al., 2018; LEONG; HERST; KANE, 2018). On the other hand, teachers and instructors 
state that the use of VR tools can make students much more active and involved in discussions and questioning (LEONG; HERST; KANE, 2018).

VR simulation tools applied to health, such as those used with virtual patients, improve medical decision making and communication for health care. Virtual patients allow a better interaction between students and their patients, can contribute to decrease anxiety in decision-making situations, increase empathy with patients, train their communication skills and a greater motivation to learn (CONCANNON; ESMAIL; ROBERTS, 2020; COURTEILLE et al., 2018; GUETTERMAN et al., 2019; PADILHA et al., 2019; SHAO et al., 2020; TSCHOLL et al., 2018).

Studies that compared the acquisition of knowledge of health students between the use of the traditional method and the use of patients in virtual reality did not find significant difference in the acquisition or retention of knowledge (CONCANNON; ESMAIL; ROBERTS, 2020; COURTEILLE et al., 2018; PADILHA et al., 2019). Regarding learning, the effect of teaching with virtual reality on theoretical knowledge reveals that the scores related to basic content, as theory, location, adjacent structure, clinical manifestation, diagnosis and analysis, surgical methods and total score in the VR group exceed those in the traditional teaching group and that the VR teaching group was significantly better than the traditional teaching group (LAM et al., 2019; SAPKAROSKI et al., 2018; SHAO et al., 2020). Technology using virtual games also provides better results in student learning and engagement in the classroom and group work (COURTEILLE et al., 2018; GUETTERMAN et al., 2019; LAM et al., 2019; PADILHA et al., 2019; SHAO et al., 2020).

Immersive VR simulation environments facilitate new ways for users to visualize anatomy and quantify performance, they help develop communication skills and interactions among students (CONCANNON; ESMAIL; ROBERTS, 2020; MAICHER et al., 2017; MIRGHANI et al., 2018; SAPKAROSKI et al., 2018). In a VR simulator training with the participation of undergraduate dentistry students to detect differences in motor performance among students with different levels of training experience, showed sensitivity to differences in performance among students, both in new and experienced students (MIRGHANI et al., 2018). The effectiveness of immersive VR in reducing stateanxiety in Occupational Therapy students who were preparing for the Structured Objective Clinical Examination (OSCE) revealed that students who had access to clinical 
VR simulation, through standardized virtual patients, using natural language, showed less anxiety compared to traditional methods (CONCANNON; ESMAIL; ROBERTS, 2020).

Virtual Reality goes beyond that used in undergraduate education, extends to surgical planning and training in the hospital environment, enables facilitated communication and a wide range of therapeutic interventions that include the treatment of phobias, anxiety disorders, post-traumatic stress disorder and deficits caused by accidents and other practices (BING et al., 2019; CECIL et al., 2018; CONCANNON; ESMAIL; ROBERTS, 2020; KONGE et al., 2015; MIRGHANI et al., 2018; MORO et al., 2017; SAPKAROSKI et al., 2018, 2019; YAO; CHALLEN; CAVES, 2019; ZAVERI et al., 2016). It has been used as a great ally in the training of technical skills of health professionals in the health area, in virtual simulation environments, providing better results in the procedures performed on patients. Thus, virtual reality has become an ally in the training of technical skills, preparing more competent professionals, with adequate knowledge and skills to work in professional practice (BANIASADI; AYYOUBZADEH; MOHAMMADZADEH, 2020; MORO et al., 2017; SAPKAROSKI et al., 2018; SUTHERLAND et al., 2019).

When the competency of physicians who performed virtual reality simulator training was evaluated through a tool developed for this purpose, virtual reality simulator training proved to be more effective than traditional learning training. This can be attributed that VR simulators allow trainees maximum practical time in a standardized and relatively stressful environment for longer, while traditional clinical training is naturally dependent on available patients (KONGE et al., 2015; ZAVERI et al., 2016). Findings ratified by the validation study of training for medical procedure (hysterectomy), in which participants with less surgical experience became more efficient in terms of time with successive simulations than those with more surgical experience (BING et al., 2019).

Projects with immersive VR experiences for workforce training can be developed for healthcare workers, in which VR immersion training is shown to be an effective teaching method to help healthcare professionals develop empathy intuitively and allow them to get an overview of the patient's condition more quickly (BING et al., 2019; DYER; SWARTZLANDER; GUGLIUCCI, 2018; TSCHOLL et al., 2018; WONG et al., 2018). In this sense, regarding the use of virtual reality for health professionals, instructors recommend it as a potential learning tool for all, both novice and experienced, 
and point out that many gaps in the education of current health professionals can be addressed using VR-enabled learning and evaluation activities (WONG et al., 2018).

\section{Considerations about the applicability of virtual reality in healthcare}

The possibilities of applicability of virtual reality as a technology for training health professionals have been expanded, given the extension of the perspectives of use and technological advancement. However, there is still a long way to go to make it widely accepted by medical education, including the development and innovation of software and hardware and the strengthening of the optimal relationship with clinical practice (SHAO et al., 2020).

Have been observed that VR can be used for teaching/professional training in the development of surgical skills, pediatric sedation, dentist motor performance, clinical reasoning and imaging exam performance (COURTEILLE et al., 2018; LEONG; HERST; KANE, 2018; MIRGHANI et al., 2018; PADILHA et al., 2019; SAPKAROSKI et al., 2019; ZAVERI et al., 2016). Most of the findings reported better performance using virtual reality when compared to the traditional mode (COURTEILLE et al., 2018; PADILHA et al., 2019; SAPKAROSKI et al., 2019).

This advantage was pointed out either in teaching to academics or in-service training for trained professionals, to improve a particular technique. The studies that indicated the advantages in teaching emphasize the possibility of taking the laboratory into the student's home, in order to enable learning at the rhythm of each student, besides allowing students to learn using different styles instead of listening in traditional pedagogical teaching practices (LAM et al., 2019; SAPKAROSKI et al., 2018; WONG et al., 2018).

When analyzing the performance in surgical procedures, it was observed that the more often the simulation was practiced and the fewer days occurred between sessions, the faster the participants performed the simulation. In addition, there was an interaction between the number of simulations performed and the level of experience, in which participants with less surgical experience became more efficient in terms of time with successive simulations than those with more surgical experience (BING et al., 2019. 
Another important point highlighted was the possibility of reducing the occurrence of intraoperative complications (SHAO et al., 2020).

Therefore, the use of VR simulation was placed as an alternative to the patients' workload in front of the patient having been reduced, aiming at patient safety. This fact causes a decrease in the possibilities of in-service training, consequently, students experience fewer opportunities with clinical cases in general and with rare cases in particular (COURTEILLE et al., 2018).

Few studies have highlighted negative points in the use of virtual reality (GUETTERMAN et al., 2019; TAUBERT et al., 2019). The immersion was pointed out as negative, by some participants, who justified that being fully immersed can make future students feel a little vulnerable, because they would not be able to see who was close to them when fully immersed in VR. Another disadvantage mentioned was the difficulty in handling the tool used in VR, besides the impossibility of taking notes during the use of VR (TAUBERT et al., 2019). Another factor considered as limiting the use of virtual reality is the mechanics and lack of variability in the conversation caused by very repetitive training, because individuals practiced speech and repeated each scenario after receiving feedback (GUETTERMAN et al., 2019).

There are more findings that indicate advantages than disadvantages in the use of virtual reality as an educational technology in health. It is believed that finding the balance in the hybridization of the learning process is one of the new challenges in the training of professionals in the health area, ratified by Courteille et al. by supporting the use of VR in medical education as a complement to traditional teaching formats (COURTEILLE et al., 2018). In addition, and unlike traditional lectures, the VR learning format accommodates various learning styles and offers a more active involvement in procedural training, which is beneficial for the development of clinical skills (COURTEILLE et al., 2018).

There is little objective quantitative evidence to evaluate any potential benefits in the use of virtual reality for the purpose in question (SAPKAROSKI et al., 2019). And as a proposition, it is emphasized that future studies should focus on when and how VRbased educational formats are most effective and should consider human factors such as gender, learning styles, and competence in information technology (COURTEILLE et al., 2018). 
Regarding costs, the results of studies that have evaluated the effectiveness of virtual reality training on participant performance bring to the forefront the question of the value of virtual reality in medical education. Educators need to carefully evaluate the balance between cost, time, availability of results data, and generalization for various environments and audiences before deciding to build or invest in virtual reality (ZAVERI et al., 2016).

Some studies have pointed out that the use of virtual reality can be applied at low cost (BING et al., 2019; MAICHER et al., 2017; SAPKAROSKI et al., 2018; SHAO et al., 2020; YAO; CHALLEN; CAVES, 2019). The first presents that the simulation was designed to be performed with low-cost standard computer game equipment, so that it can be more easily scaled in surgical training programs in less resourced environments. While a low-cost VR surgical simulation training platform can strengthen training in less resourced environments, it can also be used in environments with higher resources (BING et al., 2019). Another example was brought by presenting that standardized virtual patient simulations have the potential to reduce costs, faculty time, and resources needed to help students develop their communication skills, and interactions can be standardized among students (MAICHER et al., 2017).

These results continue to question the true value of virtual reality (ZAVERI et al., 2016). In a controversial opinion, it is believed that VR allows a competencies-based education and evaluate that, consequently, allows a level of deep learning and the development of clinical skills. Virtual clinical simulation can contribute to reduce clinical error and improve health care safety and quality (PADILHA et al., 2019).

\section{CONCLUSION}

The study made it possible to identify the characteristics of the use of VR and some considerations about the applicability of virtual reality in the health area. As a contribution, this review can serve as a guide for the expansion of this technology, while pointing out the potentialities and weaknesses of the use of virtual reality as a training technology in the health area.

\section{ACKNOWLEDGEMENTS}

To SAMSUNG Electronics from Amazon, through Federal Law No. 8,387/1991, in accordance with Article 39 of Decree No. 10,521/2020, for enabling the promotion of 
research and technological development in the region in partnership with the University of the State of Amazonas and the Una-SUS Amazon Research and Development Center of that university.

\section{REFERENCES}

BANIASADI, T.; AYYOUBZADEH, S. M.; MOHAMMADZADEH, N. Challenges and practical considerations in applying virtual reality in medical education and treatment. Oman Medical Journal, [S. l.], v. 35, n. 3, p. 1-10, 2020.

BING, E. G. et al. Using low-cost virtual reality simulation to build surgical capacity for cervical cancer treatment. Journal of Global Oncology, [S. l.], v. 2019, n. 5, p. 1-7, 2019.

CECIL, J. et al. A network-based virtual reality simulation training approach for orthopedic surgery. ACM Transactions on Multimedia Computing, Communications and Applications, [S. l.], v. 14, n. 3, 2018.

CONCANNON, B. J.; ESMAIL, S.; ROBERTS, M. R. Immersive virtual reality for the reduction of state anxiety in clinical interview exams: Prospective cohort study. [S. l.: s. n.]

COUPERUS, K. et al. Immersive Virtual Reality Medical Simulation: Autonomous Trauma Training Simulator. Cureus, [S. l.], v. 12, n. 5, p. 8-12, 2020.

COURTEILLE, O. et al. Learning through a virtual patient vs. recorded lecture: a comparison of knowledge retention in a trauma case. International journal of medical education, [S. l.], v. 9, p. 86-92, 2018.

DYER, E.; SWARTZLANDER, B. J.; GUGLIUCCI, M. R. Using virtual reality in medical education to teach empathy. Journal of the Medical Library Association, [ $S$. l.], v. 106, n. 4, p. 498-500, 2018.

EROLIN, C.; REID, L.; MCDOUGALL, S. Using virtual reality to complement and enhance anatomy education. Journal of Visual Communication in Medicine, [S. l.], v. 42, n. 3, p. 93-101, 2019.

GUETTERMAN, T. C. et al. Medical students' experiences and outcomes using a virtual human simulation to improve communication skills: Mixed methods study. Journal of Medical Internet Research, [S. l.], v. 21, n. 11, 2019.

KONGE, L. et al. Simulator training for endobronchial ultrasound: A randomised controlled trial. European Respiratory Journal, [S. l.], v. 46, n. 4, p. 1140-1149, 2015 .

LAM, J. T. et al. Use of virtual games for interactive learning in a pharmacy curriculum. Currents in Pharmacy Teaching and Learning, [S. l.], v. 11, n. 1, p. 51- 
$57,2019$.

LEONG, A.; HERST, P.; KANE, P. VERT, a virtual clinical environment, enhances understanding of radiation therapy planning concepts. Journal of Medical Radiation Sciences, [S. l.], v. 65, n. 2, p. 97-105, 2018.

MAICHER, K. et al. Developing a conversational virtual standardized patient to enable students to practice history-taking skills. Simulation in Healthcare, [S. l.], v. 12, n. 2, p. 124-131, 2017.

MIRGHANI, I. et al. Capturing differences in dental training using a virtual reality simulator. European Journal of Dental Education, [S. l.], v. 22, n. 1, p. 67-71, 2018.

MORO, C. et al. The effectiveness of virtual and augmented reality in health sciences and medical anatomy. Anatomical Sciences Education, [S. l.], v. 10, n. 6, p. 549-559, 2017.

PADILHA, J. M. et al. Clinical virtual simulation in nursing education: Randomized controlled trial. Journal of Medical Internet Research, [S. l.], v. 21, n. 3, p. 1-9, 2019.

PARK, M. J. et al. A literature overview of virtual reality (VR) in treatment of psychiatric disorders: Recent advances and limitations. Frontiers in Psychiatry, [S. l.], v. 10, n. July, p. 1-9, 2019.

SAMADBEIK, M. et al. The Applications of Virtual Reality Technology in Medical Groups Teaching. Journal of advances in medical education \& professionalism, [ $S$. l.], v. 6, n. 3, p. 123-129, 2018.

SAPKAROSKI, D. et al. The implementation of a haptic feedback virtual reality simulation clinic with dynamic patient interaction and communication for medical imaging students. Journal of Medical Radiation Sciences, [S. l.], v. 65, n. 3, p. 218 225, 2018.

SAPKAROSKI, D. et al. Quantification of Student Radiographic Patient Positioning Using an Immersive Virtual Reality Simulation. Simulation in Healthcare, [S. l.], v. 14, n. 4, p. 258-263, 2019.

SHAO, X. et al. Virtual reality technology for teaching neurosurgery of skull base tumor. BMC Medical Education, [S. l.], v. 20, n. 1, p. 1-7, 2020.

SILVA, R. D. D. C. et al. Reducing the Schizophrenia Stigma: A New Approach Based on Augmented Reality. Computational Intelligence and Neuroscience, [S. l.], v. 2017, 2017.

SUTHERLAND, J. et al. Applying Modern Virtual and Augmented Reality Technologies to Medical Images and Models. Journal of Digital Imaging, [S. l.], v. 32, n. 1, p. 38-53, 2019.

TAUBERT, M. et al. Virtual reality videos used in undergraduate palliative and 
oncology medical teaching: Results of a pilot study. BMJ Supportive and Palliative Care, [S. l.], v. 9, n. 3, p. 281-285, 2019.

TSCHOLL, D. W. et al. User perceptions of avatar-based patient monitoring: A mixed qualitative and quantitative study. BMC Anesthesiology, [S. l.], v. 18, n. 1, p. 1-11, 2018.

WONG, M. A. M. E. et al. Clinical instructors' perceptions of virtual reality in health professionals' cardiopulmonary resuscitation education. SAGE Open Medicine, [S. l.], v. 6, p. $205031211879960,2018$.

YAO, P.; CHALLEN, C.; CAVES, C. An experimental study on usefulness of virtual reality $360^{\circ}$ in undergraduate medical education [letter]. Advances in Medical

Education and Practice, [S. l.], v. 10, p. 1103-1104, 2019.

ZAVERI, P. P. et al. Virtual Reality for Pediatric Sedation: A Randomized Controlled Trial Using Simulation. Cureus, [S. l.], v. 8, n. 2, p. 1-11, 2016. 